\title{
KEGIATAN PROMOSI PERPUSTAKAAN MELALUI INSTAGRAM KAITANNYA DENGAN PERUBAHAN SIKAP FOLLOWERS
}

(Studi Korelasional Mengenai Hubungan Promosi Perpustaakaan Kementrian Pendidikan Dan Kebudayaan RI Melalui Instagram @perpustakaandikbud dengan Perubahan Sikap Followers)

\author{
Amara Derlika Salwa Putri*), Yunus Winoto**), Encang Saepudin***) \\ Universitas Padjadjaran, Bandung, Indonesia \\ email : aderlika@gmail.com*), yunus.winoto@unpad.ac.id ${ }^{* *}$ ), \\ encang.saepudin@unpad.ac.id ${ }^{* *}$ )
}

Naskah diterima: 3 Juni; direvisi: 9 Juni; disetujui: 11 Juni 2019

\begin{abstract}
Abstrak
Penelitian ini bertujuan untuk mengetahui hubungan antara promosi yang dilakukan Perpustakaan Kementrian Pendidikan dan Kebudayaan Republik Indonesia melalui akun instagram @perpustakaandikbud dengan perubahan sikap followers dilihat dari aspek kognitif, afektif, dan konatif. Teori yang digunakan dalam penelitian ini adalah Teori Cognitive Response (respon kognitif) yang mengasumsikan proses kognitif yang mendasari perubahan sikap setelah pengguna diterpa oleh iklan atau media promosi. Metode yang digunakan dalam penelitian ini adalah kuantitatif korelasional. Teknik sampling yang digunakan yaitu simple random sampling (sampel acak sederhana). Teknik pengumpulan data menggunakan kuesioner, pengamatan, wawancara dan studi kepustakaan. Penyebaran kuesioner dilakukan dengan cara mengirimkan link kuesioner yang dibuat melalui Google Form.Berdasarkan hasil penelitian menunjukkan bahwa hubungan antara promosi yang dilakukan Perpustakaan Kementrian Pendidikan dan Kebudayaan Republik Indonesia melalui akun instagram @perpustakaandikbud memiliki hubungan yang tinggi dengan perubahan sikap responden. Terdapat hubungan yang tinggi antara daya tarik promosi dengan aspek kognitif, isi pesan promosi dengan aspek kognitif dan isi pesan promosi dengan aspek afektif. Terdapat hubungan yang cukup pasti antara intensitas penggunaan dengan aspek kognitif, daya tarik promosi dengan aspek afektif, daya tarik promosi dengan aspek konatif, isi pesan promosi dengan aspek konatif. Dan terdapat hubungan yang rendah tapi pasti antara intensitas penggunaan dengan aspek afektif, intensitas penggunaan dengan aspek konatif.
\end{abstract}

Kata kunci: promosi perpustakaan, media sosial, instagram, perpustakaan, sikap

\begin{abstract}
This research aims to determine the correlation between promotions carried out by the Indonesian Ministry of Education and Culture Library through the @perpustakaandikbud Instagram account with changes in followers' attitudes seen from cognitive, affective, and conative aspects. The theory used in this study is Cognitive Response theory which assumes the cognitive processes that underlie attitude change after the user is exposed to advertising or promotional media. The method used in this study is quantitative correlational. The sampling technique used is simple random sampling. The technique of collecting data uses questionnaires, observations, interviews and literature studies. Distribution of questionnaires is done by sending a questionnaire link made through Google Form. Based on the results of the research indicate that the relationship between the promotion carried out by the Ministry of Education and Culture through the @perpustakaandikbud Instagram account has a high correlation with a respondent attitude change. There is a high relationship between the attractiveness of promotion with cognitive attitudes, the content of promotional messages with cognitive attitudes and the contents of promotional messages with affective
\end{abstract}


attitudes. There is a fairly definite relationship between the intensity of use with cognitive attitudes, the attractiveness of promotion with affective attitudes, the attractiveness of promotions with conative attitudes, the content of promotional messages with conative attitudes. And there is a low but sure relationship between the intensity of use and affective attitude, the intensity of use with a conative attitude.

\section{Keyword: library promotion, social media, instagram, attitude}

\section{PENDAHULUAN}

Perkembangan zaman telah mengubah peradaban manusia ke arah berbasis teknologi dan komunikasi. Seperti dalam dunia bisnis di Indonesia saat ini, persaingan untuk selalu menciptakan pelayanan yang terbaik bagi pelanggan merupakan cara mereka untuk dapat bertahan dalam era persaingan global. Hal ini mendorong perubahan strategi para pemasar dalam cara mereka dalam mengemas produk baik itu barang maupun jasa agar dapat menarik pelanggan. Kegiatan promosi harus dilakukan yang mana bertujuan untuk mencapai tujuan lembaga serta mempertahankan eksistensinya di masyarakat. Selain itu pemahaman terhadap pelanggan juga menjadi satu faktor penting, karena semakin memahami pelanggan maka semakin kuat sebuah perusahaan untuk berkompetisi dengan pesaingnya. Karena bukan perkara yang mudah untuk tetap bertahan di tengah persaingan jika tidak melakukan promosi dengan baik dan efektif karena menyangkut pada keuntungan-keuntungan yang akan diperoleh pada periode yang diharapkan maupun untuk kelangsungan kedepannya.

Dalam pelaksanaan kegiatan promosi diperlukan strategi komunikasi yang baik. Promosi dengan komunikasi merupakan dua hal yang tidak dapat dipisahkan. Karena menyangkut pada informasi yang berkaitan dengan produk atau jasa yang akan disampaikan kepada pelanggan. Untuk mengkomunikasikan segala bentuk informasi kepada pelanggan tentu diperlukan media yang dapat mempermudah penyampai informasi tersebut. Kegiatan komunikasi seperti ini dikenal dengan komunikasi pemasaran, yang dilakukan untuk mencapai tujuan perusahaan/ individu yang bersangkutan. Berkaitan dengan pengertian komunikasi pemasaran diartikan sebagai aktivitas pemasaran yang berusaha menyebarkan informasi, mempengaruhi/membujuk, dan mengingatkan pasar sasaran atas perusahaan dan produknya agar bersedia menerima, membeli dan loyal pada produk yang ditawarkan perusahaan yang bersangkutan (Priansa, 2017: 96)

\begin{abstract}
Komunikasi pemasaran memegang peranan yang sangat penting bagi perkembangan usaha, karena dengan adanya komunikasi pemasaran maka masyarakat akan mengetahui keberadaan produk/jasanya yang dipasarkan. Komunikasi pemasaran merupakan pendorong untuk meningkatkan penjualan sehingga tujuan suatu perusahaan/ individu dapat dipenuhi.
\end{abstract}

Pada era digital seperti saat ini, perkembangan teknologi komunikasi dan informasi seolah dapat memenuhi segala kebutuhan masyarakat. Jika dikaitkan dengan keadaan saat ini, teknologi sangat melekat dengan kehidupan masyarakat indonesia seharihari, contoh nyata seperti kehadiran surat kabar cetak yang kini juga memiliki versi digital (online), atau bahkan memiliki website. Hal ini merupakan respon dari kehadiran surat kabar terhadap kemajuan teknologi. Banyak perusahaan media cetak yang melakukan pembaruan pada strategi pemasaran mereka. Hal ini tentu bukan hal yang terlalu mengejutkan bahwa masyarakat Indonesia lebih senang menggunakan smarthphone untuk memenuhi segala kebutuhan informasi mereka.

Perkembangan teknologi komunikasi telah memunculkan suatu jenis media baru yang saat ini dikenal dengan istilah new media, yaitu internet. Dengan berbagai jenis platform yang tersedia, mulai dari Facebook, Twitter, Path, Youtube, Line, Whatsapp, Instagram, dan lainlain. Menurut Kaplan Andreas M dan Haenlein dalam Suryani (2014: 123-138) media sosial yaitu sebuah kelompok aplikasi berbasis internet yang dibangun berdasarkan fondasi ideologis dan teknologi dari web 2.0, yang memungkinkan terjadinya penciptaan dan pertukaran konten yang diciptakan oleh penggunanya. Sudah banyak perusahaan bisnis maupun jasa yang menggunakan media sosial sebagai sarana kegiatan promosi mereka. Dengan adanya media sosial kini memperkenalkan produk kepada konsumen menjadi semakin mudah, selain lebih menguntungkan dari segi waktu, biaya dan tenaga promosi melalui media sosial juga dapat 
menjangkau sasaran lebih luas. Perkembangan teknologi komunikasi kini telah memiliki pengaruh besar dalam kelangsungan hidup manusia khususnya dalam bidang pemasaran.

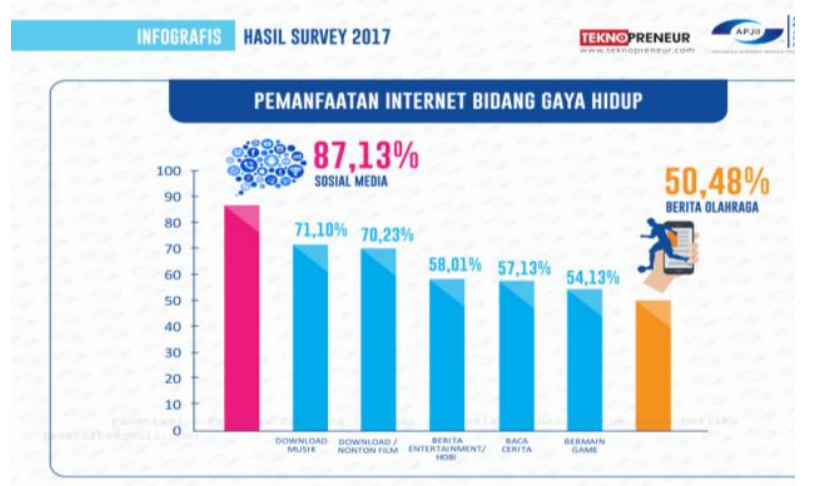

\section{Gambar 1 Pemanfaatan internet bidang gaya hidup}

Berdasarkan survey yang dilakukan oleh Asosiasi Penyelenggara Jasa Internet Indonesia (APJII) pada tahun 2017, diketahui bahwa pemanfaatan internet masyarakat Indonesia untuk penggunaan social media mengungguli penggunaan di bidang lain yang mencapai presentase $87,13 \%$. Selain menggunakan internet untuk membuka social media, pada presentase penduduk Indonesia cenderung internet untuk mendownload musik sebanyak $71,10 \%$, download/ menonton film sebanyak $70,23 \%$, berita entertainment/hobi sebanyak $58,01 \%$, baca berita sebanyak $57,13 \%$, bermain games sebanyak 54,13\%, kemudian berita olahraga sebanyak 50,48\% yang menduduki presentasi paling kecil. Hal ini menunjukkan bahwa masyarakat Indonesia cenderung memanfaatkan internet untuk membuka social media.

Dari sekian banyak media sosial yang ada, penggunaan media sosial Instagram mengalami peningkatan pengguna sangat pesat serta menjadi urutan media sosial dengan pengguna terbanyak. Dikutip dari tekno kompas, monthly active user (MAU) atau pengguna aktif bulanan Instagram menembus jumlah 1 miliar per Juni 2018. Pertumbuhan penggunaan Instagram paling signifikan dibandingkan dengan Facebook dan Snapchat yaitu mencapai 5 persen dari kuartal ke kuartal (QoQ), yang mana pertumbuhan MAU Facebook hanya mencapai 3,14 persen.

Instagram sendiri saat ini menjadi media sosial yang sangat digandrungi oleh masyarakat Indonesia. Instagram merupakan satu dari sekian banyak media sosial yang memungkinkan penggunanya untuk berbagi foto dan video. Pada awal kemunculannya, instagram hanya memfasilitasi pengguna untuk mengunggah foto dan video. Foto yang ingin di unggah dapat dipercantik dengan filter foto yang tersedia, sedangkan untuk video pengguna hanya dapat mengunggah video dengan durasi pendek yaitu 60 detik saja. Namun seiring dengan popularitas penggunaannya yang sangat pesat, kini instagram memiliki banyak fitur-fitur tambahan seperti instastory, live, tambahan jenis filter, berbagai macam emotikon, hingga arsip koleksi foto. Instagram memberikan kualitas serta tampilan foto yang baik sehingga cocok untuk dijadikan sebagai media promosi yang mengandalkan estetika foto dari konten yang akan diunggah, haruslah dibuat semenarik mungkin agar dapat menarik perhatian pengguna lainnya.

Saat ini instagram tidak hanya sekedar media sosial untuk berbagi foto dan video saja, namun dijadikan media yang dimanfaatkan untuk melakukan promosi. Sudah banyak pemasar yang memanfaatkan instagram sebagai media untuk memperkenalkan produk mereka. Baik itu di bidang kuliner, wisata, fashion, produk retail, hingga lembaga yang bergerak di bidang jasa, seperti perpustakaan.

Perpustakaan saat ini sudah banyak yang menggunakan media sosial sebagai penghubung untuk menjalin komunikasi dengan masyarakat pengguna. Perpustakaan Kementrian Pendidikan dan Kebudayaan RI salah satu dari sekian banyak perpustakaan yang melakukan promosi perpustakaan dengan memanfaatkan Instagram. Perpustakaan Kemdikbud melihat peluang dari fenomena media sosial yang terjadi saat ini, yang mana perpustakaan harus dapat berkembang secara dinamis dalam menghadapi segala bentuk perubahan-perubahan yang ada, karena mau tidak mau penggunaan internet khususnya media sosial sudah menjadi kebutuhan pada masyarakat Indonesia.

Dalam usahanya untuk memperkenalkan produk dan layanan yang dimilikinya, Perpustakaan Kemdikbud telah melakukan promosi melalui berbagai media seperti brosur, website, event-event yang diselenggarakan secara mandiri maupun hasil kerjasama dengan komunitas, dan media sosial diantaranya Facebook, Twitter dan Instagram. Promosi melalui Instagram ini dilakukan dengan tujuan untuk memperkenalkan perpustakaan ke dunia luar. Menyesuaikan dengan perkembangan 
tekonolgi komunikasi, Perpustakaan Kemdikbud melihat peluang dari penggunaan media sosial Instagram sebagai media untuk mempromosikan produk dan layanannya.

Konten yang di promosikan di akun Instagram Perpustakaan Kemdikbud terdiri dari 2 jenis, yaitu konten utama dan konten selingan. Konten utama berisi informasi mengenai hal-hal yang menjadi fokus dari kegiatan promosi produk dan layanan yang tersedia di perpustakaan itu sendiri seperti koleksi, layanan, fasilitas yang terdapat di perpustakaan, serta acara dan kegiatan yang di adakan di perpustakaan. Sedangkan konten selingan berisi informasi di luar kegiatan promosi namun informasi yang disampaikan masih mengenai hal-hal seputar perpustakaan atau informasi yang sifatnya pengetahuan seperti tips dan trik, Library Rules, peringatan hari nasional, dan lainlain. Konten selingan ini dibuat dengan pertimbangan, agar postingan menjadi lebih bervariasi serta untuk menghindari kesan monoton. Karena mungkin orang akan bosan jika postingan terus menerus berupa konten utama.

Dilakukannya kegiatan promosi melalui akun Instagram perpustakaan Kemdikbud adalah untuk meningkatkan pemanfaatan koleksi maupun fasilitas yang ada di perpustakaan. Karena keberhasilan layanan di perpustakaan dapat diukur dari tingkat keterpakaian koleksinya. Oleh karena demikian berangkat dari hal tersebut penulis tertarik untuk meneliti kegiatan promosi perpustakaan Kemdikbud melalui Instagram kaitannya dengan perubahan sikap followersnya.

\section{LANDASAN TEORI}

\section{Pengertian Promosi}

Promosi berasal dari kata promote yang dapat dimaknai sebagai mengembangkan atau meningkatkan. Promosi merupakan salah satu bentuk kegiatan komunikasi pemasaran yang mencakup aktivitas pemasaran yang berusaha menyebarkan informasi, mempengaruhi atau membujuk serta mengingatkan target pasar sasaran pada perusahaan dan produknya agar mau untuk menerima dan membeli serta timbul sikap loyal pada produk yang ditawarkan oleh perusahaan yang bersangkutan. Promosi lebih menekankan pada aspek komunikasi persuasi yang dirancang untuk menginformasikan segala hal yang berkaitan dengan produk atau jasa dan diharapkan dapat mempengaruhi target sasaran agar mau membeli barang atau jasa yang ditawarkan. (Priansa, 2017: 99).
Adapun menurut Kotler dalam bukunya yang berjudul Marketing Insight from $A$ to $Z: 80$ Concept Every Manager Needs To Know (2003), promosi adalah bagian dari komunikasi yang terdiri dari pesan-pesan perusahaan yang didesain untuk menstimuli terjadinya kesadaran (awareness), ketertarikan (interest), dan berakhir dengan tindakan pembelian (purchase) yang dilakukan oleh pelanggan terhadap produk atau jasa perusahaan.

Dari pemaparan diatas dapat diketahui bahwa promosi merupakan bentuk strategi pemasaran yang meliputi aktivitas menyebarkan informasi, mempengaruhi serta membujuk target sasaran agar berperilaku sesuai dengan yang diharapkan perusahaan penghasil produk atau jasa, yaitu membeli atau menggunakan produk atau jasa yang ditawarkan.

Menurut Terence A.Shimp promosi memiliki fungsi diantaranya:

a) Informing (memberikan informasi)

Promosi membuat konsumen sadar akan produk-produk baru, mendidik mereka tentang berbagai fitur dan manfaat merek, serta memfasilitasi penciptaan citra sebuah perusahaan yang menghasilkan produk atau jasa. Promosi menampilkan peran informasi bernilai lainnya, dengan mengajarkan manfaatmanfaat baru dari merek yang telah ada.

b) Persuading (membujuk)

Media promosi atau iklan yang baik akan mampu mempersuasi pelanggan untuk mencoba produk dan jasa yang ditawarkan. Terkadang persuasi berbentuk mempengaruhi permintaan primer, yakni menciptakan permintaan bagi keseluruhan kategori produk. Lebih sering, promosi berupaya untuk membangun permintaan sekunder, permintaan bagi merek perusahaan yang spesifik.

c) Reminding (Mengingatkan)

Iklan menjaga agar merek perusahaan tetap segar dalam ingatan para konsumen. Saat kebutuhan muncul, yang berhubungan dengan produk dan jasa yang diiklankan, dampak promosi di masa lalu memungkinkan merek dengan mengingatkan para konsumen yang akhir-akhir ini belum membeli merek yang bersedia dan mengandung atributatribut yang menguntungkan. 
d) Adding Value (Menambah nilai)

Terdapat tiga cara mendasar dimana perusahaan bisa memberi nilai tambah bagi penawaran-penawaran mereka, inovasi, penyempurnaan kualitas, atau mengubah persepsi konsumen. Ketiga komponen nilai tambah tersebut benarbenar independen. Promosi yang efektif menyebabkan merek yang dipandang lebih elegan, lebih bergaya, lebih bergengsi, dan bisa lebih unggul dari tawaran pesaing.

e) Assisting (mendampingi upaya-upaya lain dari perusahaan)

Periklanan merupakan salah satu alat promosi. Promosi membantu perwakilan penjualan. Iklan mengawasi proses penjualan produk-produk perusahaan dan memberikan pendahuluan yang bernilai bagi wiraniaga sebelum melakukan kontak personal dengan para pelanggan yang prospektif. Upaya, waktu, dan biaya periklanan dapat dihemat karena lebih sedikit waktu yang diperlukan untuk memberi informasi kepada prospek tentang keistimewaan dan keunggulan produk jasa. Terlebih lagi iklan melegitimasi atau membuat apa yang dinyatakan klaim oleh perwakilan penjual lebih kredibel.

Rossiter dan Percy dikutip dalam Tjiptono (2002: 222) yang mengklasifikasikan tujuan promosi merupakan bagian dari komunikasi sebagai berikut:

a) Menumbuhkan persepsi pelanggan terhadap suatu kebutuhan (category need)

b) Memperkenalkan dan memberikan pemahaman tentang suatu produk kepada konsumen (brand awareness)

c) Mendorong pemilihan terhadap suatu produk (brand attitude)

d) Membujuk pelanggan untuk membeli suatu produk (brand purchase intention)

e) Mengimbangi kelemahan unsur bauran pemasaran lain (purchase facilitation)

f) Menanamkan citra produk dan perusahaan (positioning).

Promosi merupakan salah satu cara yang digunakan perusahaan untuk meningkatkan penjualan produk atau jasa yang mereka tawarkan. Pada dasarnya tujuan dari promosi adalah untuk menginformasikan, mempengaruhi dan membujuk serta meningkatkan pelanggan sasaran tentang perusahaan dan bauran pemasarannya. Sehingga diharapkan dengan dilakukannya promosi sasaran pelanggan dapat bersikap seperti apa yang diharapkan oleh perusahaan dengan melewati tahapan mulai dari menumbuhkan kesadaran atas produk atau jasa yang ditawarkan, promosi juga memfasilitasi penciptaan citra sebuah perusahaan, membujuk target sasaran untuk membeli atau menggunakan produk atau jasa yang dihasilkan, selain itu media promosi yang menjaga ingatan target sasaran mengingat hal yang berhubungan dengan produk atau jasa yang ditawarkan. Selain itu dengan melakukan promosi juga dapat lebih memahami pelanggan dengan membangun komunikasi yang baik maka dengan begitu memudahkan dalam melakukan evaluasi yang dapat nantinya menjadi bahan meningkatkan inovasi dan nilai tambah dari produk atau jasa yang dihasilkan. Maka dengan begitu diharapkan perusahaan dapat terus bersaing dengan perusahaan sejenis.

\section{Instagram Sebagai Media Sosial}

Mengenai pengertian media social menurut Kaplan Andreas M dan Haenlein dalam Suryani (2014: 128) menyebutkan bahwa media sosial yaitu sebuah kelompok aplikasi berbasis internet yang dibangun berdasarkan fondasi ideologis dan teknologi dari web 2.0, yang memungkinkan terjadinya penciptaan dan pertukaran konten yang diciptakan oleh penggunanya. Adapun karakteristik media sosial dalam buku Rulli Nasrullah yang berjudul Media Sosial (2015: 16 - 23), yaitu:

a) Jaringan (network)

Seperti yang sudah di paparkan sebelumnya mengenai definisi media sosial, bahwa perilaku sosial yang terjadi antara pengguna media sosial layaknya aktivitas sosial yang terjadi di kehidupan nyata. Karakter media sosial adalah membentuk jaringan dan menyediakan perantara bagi pengguna, tidak memandang apakah pengguna tersebut saling mengenal atau tidak di kehidupan nyata, namun mereka dapat saling terhubung secara mekanisme teknologi. Jaringan yang terbentuk ini kemudian memunculkan nilai - nilai seperti ciri masyarakat dalam teori sosial.

b) Informasi (Information)

Informasi menjadi komoditas utama di media sosial dan sebenarnya informasi itu di produksi dan dan didistribusikan antarpengguna itu sendiri. Industri media sosial, seperti perusahaan Facebook, 
Twitter atau Instagram, juga menggunakan informasi sebagai sumber daya. Dari sisi institusi, media sosial dibangun berdasarkan informasi yang dikodekan (encoding) yang kemudian didistribusikan melalui berbagai perangkat hingga akhirnya dapat diakses oleh pengguna (decoding). Kemudian dari sisi pengguna, informasi menjadi landasan untuk saling berinteraksi dan membentuk masyarakat yang berjejaring. Selain itu, setiap orang yang ingin masuk ke media osial harus menyertakan informasi pribadinya (terlepas dari data asli atau yang dibuat-buat) untuk dapat memiliki akun dan mengaksesnya kemudian.

c) Arsip (archieve)

Semua informasi yang ada di media sosial tersimpan dan dapat diakses kapan pun. Informasi yang telah diposting tidak akan hilang begitu saja, tetapi informasi ini akan terus tersimpan dengan jangka waktu yang tidak terbatas. Contohnya seperti data pribadi pengguna, kumpulan foto atau video yang diunggah, postingan yang kita sukai, hingga dengan siapa saja pengguna membentuk jaringan pertemanan.

\section{d) Interaksi (interactivity)}

Interaksi dalam kajian media merupakan salah satu pembeda antara media lama (old media) dengan media baru (new media). Dalam konteks ini, David Holmes (2005) dalam (Nasrullah, 2016:26) menyatakan bahwa dalam media lama pengguna atau khalayak media merupakan khalayak yang pasif dan cenderung tidak mengetahui satu sama lain; sementara itu di media baru (new media) pengguna dapat berinteraksi, baik antara pengguna dengan pengguna maupun dengan produser konten media.

Kemudian mengenai pengertian instagram menurut Bambang dalam Atmoko (2012: 10) menyatakan bahwa instagram adalah sebuah aplikasi dari smartphone yang khusus untuk media sosial yang merupakan salah satu dari media digital yang mempunyai fungsi hampir sama dengan twitter, namun perbedaannya terletak pada pengambilan foto dalam bentuk atau tempat untuk berbagi informasi terhadap penggunaannya. Instagram juga dapat memberikan inspirasi bagi penggunanya dan juga dapat meningkatkan kreatifitas, karena Instagram mempunyai fitur yang dapat membuat foto menjadi lebih indah, lebih artistik dan menjadi lebih bagus.

\section{METODOLOGI PENELITIAN}

Metode yang dipergunakan dalam penelitian ini adalah metode korelasional. Adapun metode korelasional adalah metode yang mencari pengaruh atau hubungan diantara variabel-variabel yang diteliti. Metode korelasi ini bertujuan untuk meneliti sejauh mana variabel pada satu faktor berhubungan dengan variabel lainnya, dimana pada penelitian ini untuk mengetahui sejauh mana peran promosi melalui instagram mempengaruhi perubahan sikap followers. Untuk menguji korelasi antara kedua variabel tersebut, maka digunakan penghitungan korelasi Spearman Rnk order.

Populasi dalam penelitian ini adalah followers akun media sosial instagram @perpustakaandikbud. Followers Instagram Perpustakaan Kemendikbud dipilih sebagai objek penelitian karena berhubungan langsung dengan terpaan media promosi yang dilakukan perpustakaan kemendikbud di media sosial instagram serta dianggap memiliki ketertarikan untuk mengikuti dan menerima segala terpaan konten informasi yang di posting oleh perpustakaan.

\section{HASIL DAN PEMBAHASAN}

Sebagaimana yang telah dipaparkan di atas, penelitian ini bertujuan unutk mengetahui kegatan promosi perpustakaan Kemdikbud RI melalui Instagram dengan perubahan sikap followers". Ada dua aspek yang dikaji dalam penelitian ini yakni untuk promosi meliputi intensitas; daya tarik dan isi pesan serta aspek sikap follower. Berdasarkan hasil pengujian hipotesis diperoleh hasil sebagai berikut :

\section{1) Hubungan Antara Intensitas Dengan Sikap Follower}

Untuk pengujian yang pertama peneliti mengkaji hubungan antara intensitas penggunaan dengan sikap follower. Adapun hipotesis yang diajukan dalam penelitian ini yaitu :

$$
\begin{array}{rlr}
\mathrm{H}_{0} & \text { : Tidak ada hubungan antara intensitas } \\
& \text { penggunaan akun instagram } \\
& \text { @perpustakaandikbud } & \text { dengan } \\
& \text { perubahan sikap followers. } \\
& & \\
H_{1} & \text { : Terdapat hubungan antara intensitas } \\
& \text { penggunaan akun instagram } \\
& \text { @perpustakaandikbud } & \text { dengan } \\
& \text { perubahan sikap followers. }
\end{array}
$$


Kemudian mengenai kriteria penerimaan dan penolakan hipotesis yaitu :

1) Jika t hitung $>\mathrm{t}$ tabel atau jika taraf signifikansi $<\alpha$, maka $\mathrm{H}_{0}$ ditolak atau $\mathrm{H}_{1}$ diterima,

2) Jika t hitung $<\mathrm{t}$ tabel atau jika taraf signifikansi $>\alpha$, maka $\mathrm{H}_{0}$ diterima atau $\mathrm{H}_{1}$ ditolak.

Berdasarkan hasil pengujian hipotesis hubungan antara intensitas penggunaan dengan sikap follower.

Tabel 1

Hubungan Intensitas Penggunaan Dengan Sikap Follower

\begin{tabular}{|c|c|c|c|c|}
\hline Variabel & $\begin{array}{c}\text { Koefisien } \\
\text { korelasi } \\
\text { Rank } \\
\text { Spearman }\end{array}$ & Sig & $\boldsymbol{\alpha}$ & $\begin{array}{c}\text { Keputus } \\
\text { an }\end{array}$ \\
\hline $\begin{array}{c}\text { X2 (Daya Tarik } \\
\text { Promosi) } \\
\text { Terhadap Y1 } \\
\text { (Sikap } \\
\text { Follower) }\end{array}$ & 0,734 & 0,000 & 0,05 & $\begin{array}{c}\text { H1 } \\
\text { diterima } \\
\text { (Terdapat } \\
\text { Hubunga } \\
\text { n) }\end{array}$ \\
\hline
\end{tabular}

Berdasarkan perhitungan diatas diperoleh nilai koefisiensi korelasi sebesar 0,402 dengan taraf signifikansi 0,000 pada tingkat kepercayaan 0,05 adapun tingkat kriteria kepercayaan Dari hasil perhitungan diperoleh taraf signifikansi sebesar 0,000. Yang mana pada tingkat kriteria kepercayaan jika taraf signifikansi $<\alpha 0,05$, maka $\mathbf{H}_{\mathbf{0}}$ ditolak atau $\mathbf{H}_{1}$ diterima. Dengan demikian, dapat disimpulkan bahwa terdapat hubungan yang signifikan antara intensitas penggunaan akun instargram @perpustakaandikbud dengan sikap follower.

\section{2) Hubungan antara Daya Tarik Promosi Dengan Sikap Follower.}

Untuk pengujian yang kedua peneliti mengkaji hubungan antara daya Tarik promosi dengan sikap follower. Adapun hipotesis yang diajukan dalam penelitian ini yaitu :

$\mathrm{H}_{0}$ : Tidak ada hubungan antara daya tarik promosi pada akun instagram @perpustakaandikbud dengan perubahan sikap followers.

$H_{1}$ : Terdapat hubungan antara daya tarik promosi pada akun instagram @perpustakaandikbud dengan perubahan sikap followers.

Kemudian mengenai kriteria penerimaan dan penolakan hipotesis yaitu :
1) Jika t hitung $>t$ tabel atau jika taraf signifikansi $<\alpha$, maka $\mathrm{H}_{0}$ ditolak atau $\mathrm{H}_{1}$ diterima,

2) Jika t hitung $<\mathrm{t}$ tabel atau jika taraf signifikansi $>\alpha$, maka $\mathrm{H}_{0}$ diterima atau $\mathrm{H}_{1}$ ditolak.

Berdasarkan hasil pengujian hipotesis hubungan antara daya tarik promosi pada akun Instagram @perpustakaandikbud dengan sikap follower.

Tabel 2

Hubungan Daya Tarik Promosi Dengan Sikap Follower

\begin{tabular}{|c|c|c|c|c|}
\hline Variabel & $\begin{array}{c}\text { Koefisien } \\
\text { korelasi } \\
\text { Rank } \\
\text { Spearman }\end{array}$ & Sig & A & $\begin{array}{c}\text { Keputusa } \\
\mathbf{n}\end{array}$ \\
\hline $\begin{array}{c}\text { X1 } \\
\text { (Intensitas) } \\
\text { Terhadap } \\
\text { Y1 (Sikap } \\
\text { Follower) }\end{array}$ & 0,402 & 0,000 & 0,05 & $\begin{array}{c}\text { H1 } \\
\text { diterima } \\
\text { (Terdapat } \\
\text { Hubungan) }\end{array}$ \\
\hline
\end{tabular}

Berdasarkan perhitungan diatas diperoleh nilai koefisiensi korelasi sebesar 0,734 dengan taraf signifikansi 0,000 pada tingkat kepercayaan 0,05. Dari hasil perhitungan diperoleh nilai signifikansi sebesar 0,000. Yang mana pada tingkat kepercayaan jika taraf signifikansi $<\alpha 0,05$, maka $\mathbf{H}_{\mathbf{0}}$ ditolak atau $\mathbf{H}_{\mathbf{1}}$ diterima. Dengan demikian, dapat disimpulkan bahwa terdapat hubungan yang signifikan antara daya tarik promosi akun instagram @perpustakaandikbud dengan sikap follower.

Dari hasil perngujian hipotesis ini juga menunjukkan bahwa tampilan visual dan gaya bahasa yang digunakan akun instagram @perpustakaandikud berhubungan signifikan dengan sikap follower mengenai konten promosi Perpustakaan Kemdikbud RI di Instagram. Koefisien korelasi yang diperoleh sebesar 0,734, dimana berdasarkan kriteria Guilford menunjukkan hubungan yang tinggi antara X2 dan Y1 yang artinya daya tarik yang terdiri dari tampilan visual dan gaya bahasa yang digunakan akun instagram $@$ @erpustakaandikbud memiliki hubungan yang tinggi dengan sikap responden mengenai konten promosi Perpustakaan Kemendikbud RI di Instagram.

\section{3) Hubungan antara Isi Pesan Promosi Dengan Sikap Follower}

Untuk pengujian yang ketiga peneliti mengkaji hubungan antara isi pesan dengan 
sikap follower. Adapun hipotesis yang diajukan dalam penelitian ini yaitu :

$\mathrm{H}_{0}$ : Tidak ada hubungan antara isi pesan pada akun instagram @perpustakaan dikbud dengan perubahan sikap followers.

$H_{1}$ : Terdapat hubungan antara isi pesan pada akun instagram @perpustakaan dikbud dengan perubahan sikap followers.

Kemudian mengenai kriteria penerimaan dan penolakan hipotesis yaitu :

3) Jika t hitung $>t$ tabel atau jika taraf signifikansi $<\alpha$, maka $\mathrm{H}_{0}$ ditolak atau $\mathrm{H}_{1}$ diterima,

4) Jika $t$ hitung $<t$ tabel atau jika taraf signifikansi $>\alpha$, maka $\mathrm{H}_{0}$ diterima atau $\mathrm{H}_{1}$ ditolak.

Berdasarkan hasil pengujian hipotesis hubungan antara isi pesan pada akun Instagram @perpustakaandikbud dengan sikap follower.

Tabel 3

Hubungan Isi Pesan Promosi Dengan Sikap Kognitif

\begin{tabular}{|c|c|c|c|c|}
\hline Variabel & $\begin{array}{c}\text { Koefisien } \\
\text { korelasi } \\
\text { Rank } \\
\text { Spearman }\end{array}$ & Sig & $\boldsymbol{\alpha}$ & Keputusan \\
\hline $\begin{array}{c}\text { X3 (Isi Pesan } \\
\text { Promosi) } \\
\text { Terhadap Y1 } \\
\text { (Sikap } \\
\text { Follower) }\end{array}$ & 0,743 & 0,000 & 0,05 & $\begin{array}{c}\text { H1 } \\
\text { diterima } \\
\text { Terdapat } \\
\text { Hubungan) }\end{array}$ \\
\hline
\end{tabular}

Berdasarkan perhitungan diatas diperoleh nilai koefisien korelasi sebesar 0,743 dengan taraf signifikansi 0,000 pada tingkat kepercayaan 0,05. Dari hasil perhitungan diperoleh nilai signifikansi sebesar 0, Yang mana pada tingkat kepercayaan jika taraf signifikansi $<\alpha 0,05$, maka $\mathbf{H}_{\mathbf{0}}$ ditolak atau $\mathbf{H}_{\mathbf{1}}$ diterima. Dengan demikian, dapat disimpulkan bahwa terdapat hubungan yang signifikan antara isi pesan promosi akun instagrm $@$ perpustakaandikbud dengan sikap follower. Dari hasil pengujian hipotesis ini artinya menunjukkan bahwa dari dari segi kejelasan dan kelengkapan informasi di akun instagram $@$ @erpustakaandikbud berhubungan signifikan dengan sikap follower

\section{4) Hubungan antara Promosi Melalui Instagram Dengan Perubahan Sikap Followers}

Untuk pengujian hipotesis Maior peneliti mengkaji hubungan antara promosi melalui akun Instagram dengan sikap follower. Adapun hipotesis yang diajukan dalam penelitian ini yaitu :

$\begin{array}{rlr}\mathrm{H}_{0} & \text { : Tidak ada hubungan antara } \\ & \text { promosi melalui akun Instagram } \\ & \text { @perpustakaan dikbud dengan } \\ & \text { perubahan sikap followers. } & \\ \mathrm{H}_{1} & \text { Terdapat hubungan antara } & \text { promosi } \\ & \text { melalui akun Instagram } & \\ & \text { @perpustakaan dikbud } & \text { dengan } \\ & \text { perubahan sikap followers. } & \end{array}$

Kemudian mengenai kriteria penerimaan dan penolakan hipotesis yaitu :

5) Jika t hitung $>t$ tabel atau jika taraf signifikansi $<\alpha$, maka $\mathrm{H}_{0}$ ditolak atau $\mathrm{H}_{1}$ diterima,

6) Jika t hitung $<\mathrm{t}$ tabel atau jika taraf signifikansi $>\alpha$, maka $\mathrm{H}_{0}$ diterima atau $\mathrm{H}_{1}$ ditolak.

Berdasarkan hasil pengujian hipotesis hubungan antara promosi melalui akun instagram @perpustakaandikbud dengan sikap follower.

Tabel 4

Hubungan Promosi Perpustakaan

Kemendikbud RI Melalui Instagram Dengan Perubahan Sikap Followers

\begin{tabular}{|c|c|c|c|c|}
\hline & $\begin{array}{c}\text { Koefis } \\
\text { ien } \\
\text { korela } \\
\text { si } \\
\text { Rank } \\
\text { Spear } \\
\text { man }\end{array}$ & Sig & A & Keputusan \\
\hline $\begin{array}{c}\text { X (Promosi } \\
\text { Perpustakaa } \\
\text { n }\end{array}$ & & & & \\
Kemdikbud \\
Melalui \\
$\begin{array}{c}\text { Instagram) } \\
\text { Terhadap Y } \\
\text { (Perubahan } \\
\text { Sikap }\end{array}$ & 0,787 & 0,000 & 0,05 & $\begin{array}{c}\text { H1 diterima } \\
\text { (Terdapat } \\
\text { Followers) }\end{array}$ \\
\hline
\end{tabular}

Berdasarkan perhitungan diatas diperoleh nilai koefisiensi korelasi sebesar 0,787 dengan taraf signifikansi sebesar 0,000 pada tingkat kepercayaan 0,05. Dari hasil perhitungan diperoleh nilai signifikansi sebesar $0,000<\alpha 0,05$, maka $\mathbf{H}_{\mathbf{0}}$ ditolak atau $\mathbf{H}_{\mathbf{1}}$ diterima. Artinya terdapat hubungan yang signifikan antara promosi Perpustakaan Kemdikbud melalui instagram dengan perubahan sikap followers. Hubungan ini ditunjukkan dengan nilai korelasi sebesar 0,787 yang mana berdasarkan kriteria Guilford berada pada hubungan yang tinggi. 


\section{SIMPULAN}

Berdasarkan hasil penelitian yang telah dijabarkan pada hasil penelitian, makadapat disimpulkan bahwa terdapat hubungan yang signifikan antara promosi Perpustakaan Kemdikbud RI melalui akun instagram $@$ perpustakaandikbud (X) dengan perubahan sikap followers (Y) dengan koefisien korelasi sebesar 0,787 .

\section{DAFTAR PUSTAKA}

APJII. (t.thn.). Hasil Survei Penetrasi dan Perilaku Pengguna Internet Indonesia 2017. Dipetik Januari 10 , 2019, dari APJII: https://apjii.or.id

Ardianto, E. (2012). Komunikasi Massa. Bandung: Simbiosa Rekatama Media.

Arikunto, S. (2006). Prosedur Penelitian Suatu Pendekatan Praktik. Jakarta: Rineka Cipta.

Atmoko, B. D. (2012). Instagram Handbook Tips Fotografi Ponsel. Jakarta: Media Kita.

Azwar, S. (2013). Sikap manusia: teori dan pengukurannya. Yogyakarta: Pustaka Pelajar.

Belch, M. A., \& George, B. (1998). An Integrated Marketing.

Bohang, F. K. (2018, Juni 21). Juni 2018, Pengguna aktif Instagram tembus 1 miliar. Dipetik April 22, 2019, dari Tekno Kompas: https://tekno.kompas.com

Burhan, B. (2005). Metodologi Penelitian Kuantitatif. Jakarta: Kencana Prenada Media Grow.

Effendy, O. U. (1989). Kamus Komunikasi. Bandung: Mandar Maju.

Effendy, O. U. (1993). Ilmu Komunikasi Teori dan Praktek. Bandung: Citra Aditya Bakti.

Indonesia, K. P. (2014). Panduan optimalisasi media sosial untuk kementrian perdagangan RI. Jakarta: Pusat Hubungan Masyarakat Kementrian Perdagangan Indonesia.

Kanuk, \& Schiffman. (2007). Perilaku konsumen. Jakarta: Indeks Gramedia.
Kaplan, A. M., \& Michael Haenlein. (2010). Users of the world opportunities of social media. Bussines Horizons.

Kotler, P. (2003). Marketing insight from A to Z: 80 concepts every manager needs to know. New York: Willey.

Liliweri, A. (1992). Dasar-dasar komunikasi periklanan. Bandung: Citra Aditya Bakti.

Mar'at. (1984). Sikap manusia, perubahan serta pengukurannya. Jakarta: Ghalia Indonesia.

Nasrullah, R. (2016). Media sosial (Perspektif komunikasi, budaya dan sosioteknologi. Bandung: Rekatama Media.

Nitisemito, A. S. (1996). Manajemen personalia (Sumber daya manusia). Jakarta: Gholia Indonesia.

Priansa, D. J. (2017). Komunikasi Pemasaran Terpadu. Bandung: Pustaka Setia.

Rakhmat, J. (2005). Psikologi Komunikasi. Bandung: Remaja Rosdakarya.

Shimp, T. A. (2002). Periklanan \& Promosi: Aspek Tambahan Komunikasi Terpadu. Jakarta: Erlangga.

Shimp, T. A. (2010). Advertising promotion and other aspects of interated marketing communication. Canada: Nelson Education, Ltd.

Siegel, S. (1997). Statistik Non Parametik Untuk Ilmu-ilmu Sosial. Jakarta: Gramedia Pustaka.

Sugiyono. (2014). Metode Penelitian Kuantitatif, Kualitatif dan $R \& D$. Bandung: Alfabeta.

Sulaksana, U. (2005). Komunikasi Pemasaran. Yogyakarta: Pustaka Belajar.

Suryani, I. (2014). Pemanfaatan Media Sosial sebagai Media Pemasaran Produk dan Potensi Indonesia dalam Upaya Mendukung ASEAN COmmunity 2015. (Study Social Marketing pada Twitter Kemenparekraf RI dan Facebook Disparbud Provinsi Jawa Barat. Jurnal Komunikasi , 123 - 138.

Tjiptono, F. (2002). Pemasaran Strategik, Edisi 2. Yogyakarta: Andi Offset. 
Tjiptono, F. (2008). Strategi Pemasaran . Yogyakarta: Andi Offset.

Purwadi, Budi. 2000. Riset Pemasaran. Jakarta: Grasindo
Wahyudi. (1994). Dasar-dasar manajemen penyiaran. Jakarta: Gramedia Pustaka Utama.

Zuchdi, D. (1995). Pembentukan Sikap. Cakrawala Pendidikan, 51 - 63 